\title{
Evaluation on Toxicity Level of Terminalia catappa Leaves Extract on Selected Cyprinids under Different Bath Concentrations
}

\author{
Emi Fazlina Hashim ${ }^{1 *}$, Irence John ${ }^{1}$, Intan Faraha A Ghani ${ }^{1 *}$ and \\ Mohammad Noor Amal Azmai ${ }^{2}$ \\ ${ }^{1}$ Department of Science and Biotechnology, Faculty of Engineering and Life Sciences, \\ Universiti Selangor, 45600 Bestari Jaya, Selangor, Malaysia \\ ${ }^{2}$ Department of Biology, Faculty of Science, Universiti Putra Malaysia, \\ 43400 UPM Serdang, Selangor, Malaysia
}

\begin{abstract}
This study aimed to determine the lethal concentration $\left(\mathrm{LC}_{50}\right)$ of Terminalia catappa leaves extract on three cyprinid species; carp (Cyprinus carpio), goldfish (Carassius auratus) and tiger barb (Puntigrus tetrazona) through the acute toxicity test. The leaves of $T$. catappa were extracted with methanol and prepared in various immersion concentrations $(40,80,100,150$, 200, 250, 300, and $350 \mathrm{mg} / \mathrm{L}$ ). These extracts were immersed in the aquarium and left for $24 \mathrm{~h}$ before performing the acute toxicity test. The water quality was also analyzed before and after adding the extract immersions into the aquarium. The acute toxicity test conducted for $96 \mathrm{~h}$ with 10 fishes of each cyprinid species (4.0-6.0 cm length) in $30 \mathrm{~L}$ water capacity aquarium. The mortality of each cyprinid species was recorded at $24 \mathrm{~h}$ time interval and $\mathrm{LC}_{50}$ of the extracts throughout 96 hours was determined through the probit analysis application. Specifically, the $\mathrm{LC}_{50}$ of $T$. catappa leaves extract were $349.89,338.65$ and $318.48 \mathrm{mg} / \mathrm{L}$ exhibited for carp, goldfish and tiger barb, respectively. A high concentration range of any plant-based extract has the potential to become toxic to particular fishes. Thus, it is an effort from this study to identify the safety margin of $T$. catappa leaves extract before its therapeutic values can be further manipulated and elucidated in aquaculture research.
\end{abstract}

ARTICLE INFO

Article history:

Received: 14 June 2020

Accepted: 14 August 2020

Published: 27 November 2020

DOI: https://doi.org/10.47836/pjtas.43.4.02

E-mail addresses:

hashim.emifazlina@nies.go.jp (Emi Fazlina Hashim) cik_irence@yahoo.com (Irence John) intanfaraha@unisel.edu.my (Intan Faraha A Ghani) mnamal@upm.edu.my (Mohammad Noor Amal Azmai) * Corresponding authors
Keywords: Leaves extract, lethal concentration, mortality, ornamental fish

\section{INTRODUCTION}

The ornamental fish industry in Malaysia is expanding due to the increasing number of local fish exporters, even though there are still concerns over the economic viability and sustainability of this industry (Department 
of Fisheries [DOF], 2016). Cyprinidae considered among the popular fish families in Malaysia for the ornamental and food fish industries. Cyprinids were on the highest rank, which contributed about RM 103 million from a total of RM 341 million in ornamental fish production in 2015 (DOF, 2015). Among the cyprinid species, carp (Cyprinus carpio), goldfish (Carassius auratus) and tiger barb (Puntigrus tetrazona) are having a relatively high market demand due to its beautiful pattern and colors.

However, significant losses in many aquaculture industries from the uncontrollable disease outbreaks that emerge from various causes seemed to be unavoidable (Citarasu, 2012; Rodger, 2016). Progress in combating the diseases currently is time-consuming and has become slower through conventional protocols, since chemical drugs resistance problems are dramatically aroused (Liu et al., 2017; Song et al., 2015). To some extent, the over-dosage of antibiotics or antimicrobial treatments can spoil the captivating features and color of ornamental fishes, which ultimately affects its sale and market values (Marimuthu et al., 2012). As for issues related to the future of the ornamental fish industry, there are tremendous efforts and countless studies presently in search of alternative sources, especially from indigenous or herb plants that are convenient and harmless for disease treatments.

Terminalia catappa or locally known as 'ketapang' is a multi-purpose tree since almost all of its parts can utilize for human and animal benefits (Kadam et al., 2011). The dried leaves are said to have miraculous or therapeutic effects on the infected or injured fishes, according to locals in Southeast Asia (Chansue \& Assawawongkasem, 2008). Therefore, it is common to see the leaves submerging in the culture tanks of fish breeders or even home aquariums as protection from diseases for their cultured fishes. Terminalia catappa leaves typically contain various phytoconstituents such as tannins, isovitexin, flavonoids and triterpenoids (Citarasu, 2010), which have proven efficient as fish anti-pathogenic through many in vitro tests (Allyn et al., 2018; Fakoya et al., 2019; Purwani et al., 2015; Walczak et al., 2017). The in vivo studies through bath treatment of these leaves on the infected fishes are still scarce and selective in certain species of ornamental fishes particularly on Siamese fighting fish (Betta splendens) and guppy fish (Poecilia reticulata) (Chansue \& Assawawongkasem, 2008; Nugroho et al., 2017; Purivirojkul, 2012). Many researchers are likely more interested in the in vitro test compared to in vivo tests, as the preparations seem complicated with its toxicology and safety evaluations on live animals (Akinsanya et al., 2016; Manaharan et al., 2014). Although there are increasing numbers in plant remedy studies, their scientific works on its safety, toxicity and adverse effects for the specific host or target are not always discovered together at the same time (Kasthuri \& Ramesh, 2018; Saad et al., 2006). 
With the main focus on the immersion concentrations of $T$. catappa leaves extract, the present study aims to determine its toxicity level on the three selected cyprinid species, which are carp, goldfish and tiger barb. Information from this toxicity study would serve as an essential baseline for further studies in establishing T. catappa leaves extract as an alternative source of therapeutics against diseases in ornamental fishes.

\section{MATERIALS AND METHODS}

\section{Preparation of Terminalia catappa Extract}

The green leaves of wild-grown T. catappa were collected and dried under the sunlight for about one week with another $48 \mathrm{~h}$ drying with oven (Protech ${ }^{\circledR}$-FSD 380 ) at $40^{\circ} \mathrm{C}$. These dried leaves were pulverized to fine powders with a commercial blender (Butterfly ${ }^{\circledR}$ B-592) and freeze dried at $-45^{\circ} \mathrm{C}$ (Labconco-7750030) as preparations for methanolic extraction. The extractions were performed for about $48 \mathrm{~h}$ using $100 \mathrm{~g}$ of T. catappa leaves powder with $1000 \mathrm{~mL}$ methanol according to the method by $\mathrm{Yi}$ et al. (2012). The excessive methanol was then evaporated using rotary evaporator (Eyela-N1100) and the obtained crude extract were kept in the freezer $\left(-20^{\circ} \mathrm{C}\right)$ and used as a test solution.

\section{Preparation of Fish Culture}

The selected cyprinid species of carp (Cyprinus carpio), goldfish (Carassius auratus) and tiger barb (Puntigrus tetrazona) purchased from the local breeders; considerably similar in size (4.0$6.0 \mathrm{~cm}$ length). Prior to experiment, all fishes acclimatized under the laboratory conditions for seven days before conducting the acute toxicity test. The dissolved oxygen levels maintained within the standard concentration range for freshwater fishes between 3.0 to $7.0 \mathrm{mg} / \mathrm{L}$ (DOF, 2016) and the fishes were daily fed once with commercial fish pellet.

\section{Acute Toxicity Test}

Eight different concentrations of Terminalia catappa leave extract $(40,80,100,150,200$, 250, 300, and $350 \mathrm{mg} / \mathrm{L}$ ), each with three replicates along with one control were set up in this test. The test conducted according to the method of Ekanem et al. (2004) within $96 \mathrm{~h}$. The extracts initially immersed for $24 \mathrm{~h}$ before adding the 10 fishes of each cyprinid species into the $30-\mathrm{L}$ tank aquarium. The water was continuously aerated without any change and fed not provided throughout the test. Any dead fish found under these circumstances during the observation at every $24 \mathrm{~h}$ was isolated from the aquarium. The total of death fishes throughout $96 \mathrm{~h}$ in the respective extract concentrations was finally recorded for determining the $\mathrm{LC}_{50}$ or lethal concentration of the extracts.

\section{Water Quality Analysis}

The quality of aquarium water with nonimmersions and immersions of leaves extract was analyzed before performing the acute toxicity test. The $\mathrm{pH}$, temperature, 
dissolved oxygen and total ammonianitrogen of the water were measured using water quality probe (YSI Pro Plus). The final concentration of total ammonianitrogen was further determined using a Nessler-2458200 reagent set.

\section{Statistical Analysis}

Statistical analysis using one-way analysis of variance (ANOVA) was applied to the results of water quality analysis. The significant differences at $95 \%$ confidence level between the data samples distinguished using Duncan's multiple range test (DuncanMRT). The lethal concentration or $\mathrm{LC}_{50}$ of $T$. catappa leaves extract on the tested cyprinid species was determined using probit analysis.

\section{RESULTS}

\section{Acute Toxicity Test}

No mortality was observed within the 96 $\mathrm{h}$ exposure for all cyprinid species in the concentrations ranging from 20 to $200 \mathrm{mg} / \mathrm{L}$ (Tables 1, 2, and 3). However, the mortality significantly increased when the tested concentrations distinctly increased from 250 to $350 \mathrm{mg} / \mathrm{L}$. The highest bath concentration of $350 \mathrm{mg} / \mathrm{L}$ also demonstrated almost to $100 \%$ mortality in all cyprinid species, especially tiger barb.

Probit analysis was applied to determine the relative $\mathrm{LC}_{50}$ or lethal concentration of $T$. catappa that caused death in at least $50 \%$ from the tested cyprinid species in a specified period of $96 \mathrm{~h}$. Through this analysis, different $\mathrm{LC}_{50}$ of $T$. catappa leaves

Table 1

Mortality rate (\%) of carp ( $n=10)$ within 96 h bath immersion of Terminalia catappa leaves extract at different concentrations

\begin{tabular}{cccccccccc}
\hline \multirow{2}{*}{ Time (h) } & \multicolumn{7}{c}{ Concentrations of extract (mg/L) } \\
\cline { 2 - 10 } & Control & 40 & 80 & 100 & 150 & 200 & 250 & 300 & 350 \\
\hline 24 & 0 & 0 & 0 & 0 & 0 & 0 & 0 & 0 & 0 \\
48 & 0 & 0 & 0 & 0 & 0 & 0 & 0 & 0 & 10 \\
72 & 0 & 0 & 0 & 0 & 0 & 0 & 0 & 10 & 20 \\
96 & 0 & 0 & 0 & 0 & 0 & 0 & 20 & 20 & 50 \\
\hline Total (\%) & 0 & 0 & 0 & 0 & 0 & 0 & 20 & 30 & 80 \\
\hline
\end{tabular}

Table 2

Mortality rate (\%) of goldfish $(n=10)$ within 96 h bath immersion of Terminalia catappa leaves extract at different concentrations

\begin{tabular}{cccccccccc}
\hline \multirow{2}{*}{ Time (h) } & \multicolumn{7}{c}{ Concentrations of extract (mg/L) } \\
\cline { 2 - 10 } & Control & 40 & 80 & 100 & 150 & 200 & 250 & 300 & 350 \\
\hline 24 & 0 & 0 & 0 & 0 & 0 & 0 & 0 & 0 & 0 \\
48 & 0 & 0 & 0 & 0 & 0 & 0 & 0 & 0 & 10 \\
72 & 0 & 0 & 0 & 0 & 0 & 0 & 0 & 20 & 50 \\
96 & 0 & 0 & 0 & 0 & 0 & 0 & 20 & 20 & 30 \\
\hline Total (\%) & 0 & 0 & 0 & 0 & 0 & 0 & 20 & 40 & 90 \\
\hline
\end{tabular}


extracts were obtained on carp, goldfish and $338.65 \mathrm{mg} / \mathrm{L}$ (Figure 2), and $318.48 \mathrm{mg} / \mathrm{L}$ tiger barb with $349.89 \mathrm{mg} / \mathrm{L}$ (Figure 1), (Figure 3), respectively.

Table 3

Mortality rate (\%) of tiger barb $(n=10)$ within 96 h bath immersion of Terminalia catappa leaves extract at different concentrations

\begin{tabular}{cccccccccc}
\hline \multirow{2}{*}{ Time (h) } & \multicolumn{8}{c}{ Concentrations of extract (mg/L) } \\
\cline { 2 - 10 } & Control & 40 & 80 & 100 & 150 & 200 & 250 & 300 & 350 \\
\hline 24 & 0 & 0 & 0 & 0 & 0 & 0 & 0 & 0 & 20 \\
48 & 0 & 0 & 0 & 0 & 0 & 0 & 0 & 10 & 40 \\
72 & 0 & 0 & 0 & 0 & 0 & 0 & 10 & 10 & 40 \\
96 & 0 & 0 & 0 & 0 & 0 & 0 & 20 & 40 & 0 \\
\hline Total (\%) & 0 & 0 & 0 & 0 & 0 & 0 & 30 & 60 & 100 \\
\hline
\end{tabular}

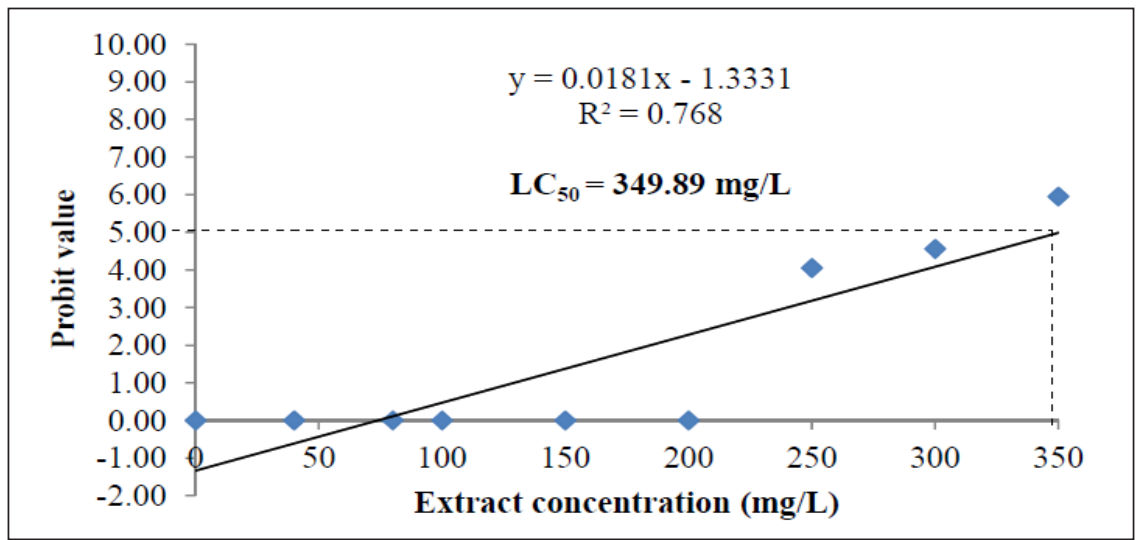

Figure 1. Probit analysis of determining the $\mathrm{LC}_{50}$ of Terminalia catappa leaves extract on carp (Cyprinus carpio) based on total mortality within $96 \mathrm{~h}$

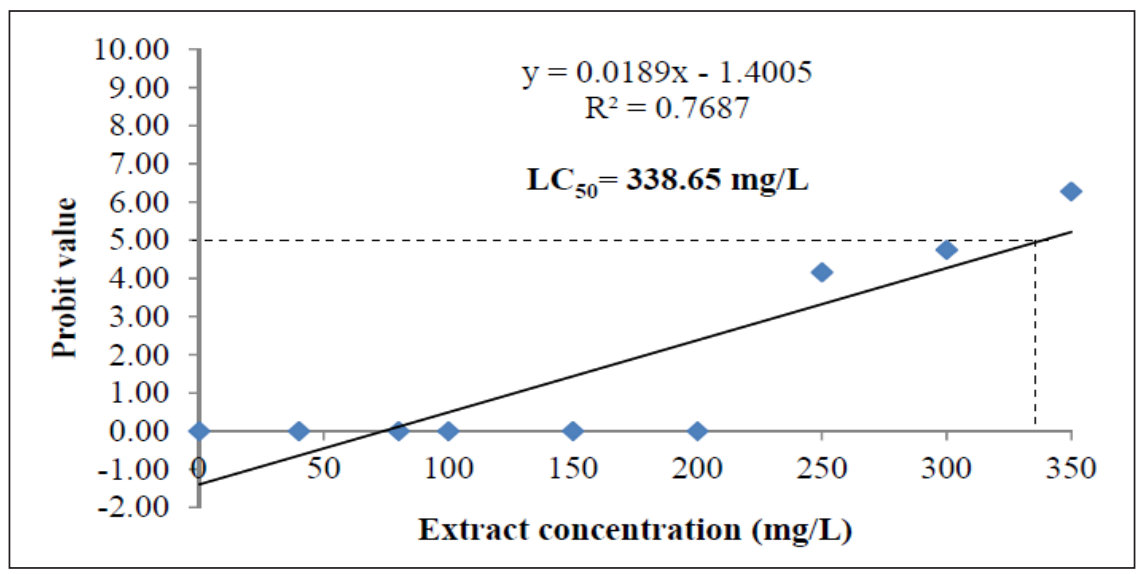

Figure 2. Probit analysis of determining the $\mathrm{LC}_{50}$ of Terminalia catappa leaves extract on goldfish (Carassius auratus) based on total mortality within $96 \mathrm{~h}$ 


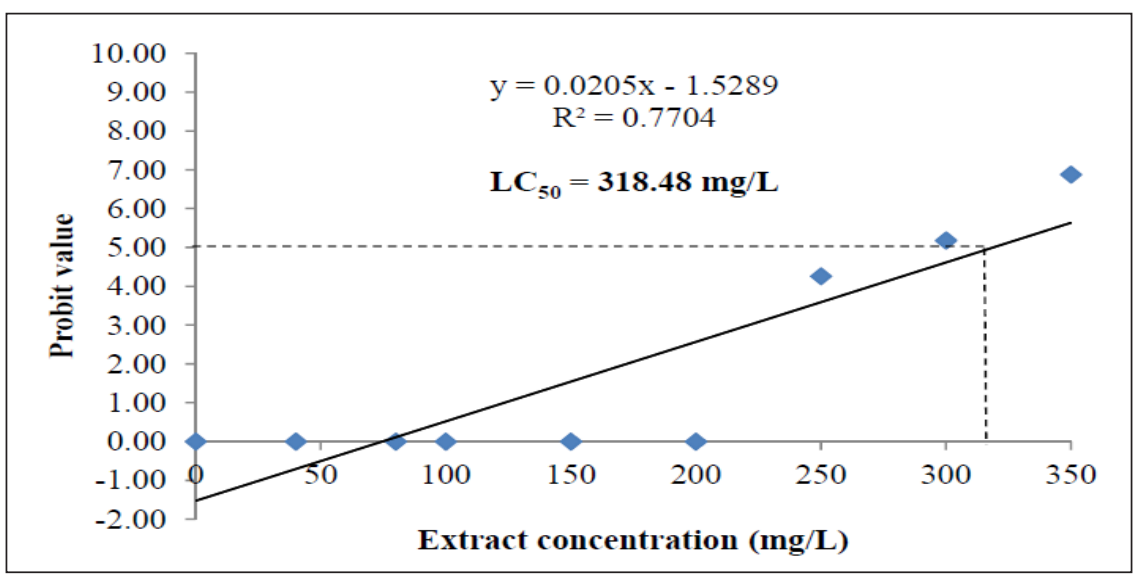

Figure 3. Probit analysis of determining the $\mathrm{LC}_{50}$ of Terminalia catappa leaves extract on tiger barb (Puntigrus tetrazona) based on total mortality within $96 \mathrm{~h}$

\section{Water Quality Analysis}

The mean values for water quality analysis showed a paralleled increment between the extract concentrations and total ammonianitrogen concentrations but conversely different between the $\mathrm{pH}$ (Table 4).

\section{DISCUSSION}

The acute toxicity test of $T$. catappa leaves extract in this study revealed at a specific concentration range of its bath immersion could cause toxic and mortality on selected cyprinid species. Our findings were in agreement with Chansue and Assawawongkasem (2008)'s as well as Stratev et al. (2018)'s studies, which stated that any natural or herbal plant source could either be beneficial or detrimental to any fish since the level of its toxicity mainly depended on the applied extract

Table 4

Water quality parameters of different concentrations of Terminalia catappa leaves extract for toxicology assessments on tested cyprinid species

\begin{tabular}{ccc}
\hline Concentration of extract $(\mathrm{mg} / \mathrm{L})$ & $\mathrm{pH}$ & Total ammonia-nitrogen $(\mathrm{mg} / \mathrm{L})$ \\
\hline Control (no extract) & $6.92 \pm 0.05^{\mathrm{a}}$ & $0.43 \pm 0.06^{\mathrm{a}}$ \\
40 & $6.75 \pm 0.04^{\mathrm{b}}$ & $0.82 \pm 0.06^{\mathrm{b}}$ \\
80 & $6.70 \pm 0.02^{\mathrm{bc}}$ & $1.15 \pm 0.06^{\mathrm{c}}$ \\
100 & $6.64 \pm 0.04^{\mathrm{cd}}$ & $1.45 \pm 0.04^{\mathrm{d}}$ \\
150 & $6.61 \pm 0.04^{\mathrm{de}}$ & $1.91 \pm 0.03^{\mathrm{e}}$ \\
200 & $6.54 \pm 0.04^{\mathrm{ef}}$ & $2.22 \pm 0.04^{\mathrm{f}}$ \\
250 & $6.51 \pm 0.03^{\mathrm{f}}$ & $2.82 \pm 0.04^{\mathrm{g}}$ \\
300 & $6.42 \pm 0.01^{\mathrm{g}}$ & $>3.5^{\mathrm{h}}$ \\
350 & $6.39 \pm 0.03^{\mathrm{g}}$ & $>3.5^{\mathrm{h}}$ \\
\hline
\end{tabular}

Note. Data (mean) showed in two replicates with standard deviation. Values with the different letter (a-h) in each column are significantly different at $\mathrm{p}<0.05$ based on Duncan-MRT 
concentrations and targeted fish physical and species. Chansue and Assawawongkasem (2008) discovered that guppy (Poecilia reticulata) and Siamese fighting (Betta splendens) fishes (approximately $2.0 \mathrm{~cm}$ in length) had different toxicity effects by water extract of T. catappa leaves. Even if they are averagely similar in size, the guppy fish was found to be more sensitive than Siamese fighting fish with the $\mathrm{LC}_{50}$ for $96 \mathrm{~h}$ of 5.6 and $7.0 \mathrm{mg} / \mathrm{L}$, respectively. Another study by Purivirojkul (2012) showed high $\mathrm{LC}_{50}(1,765.7 \mathrm{mg} / \mathrm{L})$ of the $T$. catappa leaves extract on similar fish species utilized in Chansue and Assawawongkasem (2008)'s study; Siamese fighting fish but it is slightly bigger (about $4.0 \mathrm{~cm}$ in length) than the previous one. Furthermore, the concentrated plant extracts may also contribute to a severe cause to the non-target aquatic species in certain circumstances (Singh \& Singh, 2002: Yunus et al., 2019). Therefore, a toxicological assessment of the plant extracts is indeed essential to conduct meticulously prior to usage on the targeted fish species or before other manipulation of the extract can further investigate.

The changes in $\mathrm{pH}$ value were observed where they were gradually reduced to acidic from the low to high concentrations of leaves extract in this study. These conditions were expected as $T$. catappa had the potential to lower the pH of water (Lee et al., 2016). However, T. catappa leaves extract at a low concentration ranging from 2.0 to 5.0 $\mathrm{mg} / \mathrm{L}$ had proven to be non-effective on the acidity or alkalinity of the water, according to Bryan (2016). It showed acidic (pH 6.5-
6.0) with 6.0 to $10.0 \mathrm{mg} / \mathrm{L}$ concentrations from the leaves extracted for three days using water in the study of Chansue and Assawawongkasem (2008). Most of the cultured fishes were well-tolerated with the pH ranges from 6.2 to 7.8 (Chansue, 2007; Chitmanat et al., 2005). Their growth and mortality might be affected and resulted from the rapid change of $\mathrm{pH}$ over 0.2 (Chansue \& Assawawongkasem, 2008). Stone et al. (2013) also stated almost similar findings with Chansue and Assawawongkasem (2008), where the acceptable $\mathrm{pH}$ range for most fish species was within 6.5 to 9.0 and chronic $\mathrm{pH}$ level (below 6.5) may reduce the fish reproduction. Even our concentrations of the leaves extract varied, the acidic $\mathrm{pH}$ ranges and its effects on the tested fishes showed an agreement with the previous studies. No mortality was recorded in all tested cyprinid species between 40 and $200 \mathrm{mg} / \mathrm{L}$ of leaves extracts with acidic conditions within a $\mathrm{pH}$ of 6.75 to 6.54 . The mortality of cyprinid species was only exhibited between 250 and $350 \mathrm{mg} / \mathrm{L}$ concentrations with lower $\mathrm{pH}$ than 6.54 .

In general, many factors can contribute to the $\mathrm{pH}$ changes in the fish culture environment or condition. Ikhwanuddin et al. (2014) stated that the decreased $\mathrm{pH}$ or acidic conditions in any plant-based bath immersion could be reflected from the accumulation of its organic acids especially tannins. Tannin, a polyphenolic compound commonly found in most herbal plants may be employed as a source of alternative treatments in its adequate concentration as antibacterial, antiparasitic, antiviral and 
antifungal for many fish species (Azrul et al., 2014; Chansue \& Assawawongkasem, 2008; Chitmanat et al., 2005; Yunus et al., 2019). However, the excessive and high level of tannins in the water and feed formulation showed adverse effects on herbivorous and omnivorous fishes (Azrul et al., 2014; Mandal \& Gosh, 2010). Chansue and Assawawongkasem (2008) found that heavy solid suspension adhered to the gills of guppy and Siamese fighting fishes through necropsy tests upon the completion of $T$. catappa leaves extract toxicity test. These findings could be evidence of irritation since the adhered gills were blocked for oxygen by a high concentration of tannins contained in the applied T. catappa leaves extracts. In the study of Borisutpeth et al. (2001), tannic acid at $97.5 \mathrm{mg} / \mathrm{mL}$ caused hyperplasia in epithelial cells of gill filaments, aneurysm of gill lamellae and disarray in tilapia; which ultimately died without histopathological changes in other organs within $96 \mathrm{~h}$. Accumulation of significant level of tannin also found in the different fish species of Indian major and exotic carps and its tissues (liver and kidney) because of the tannin-like compounds presented in their feeding (Mandal \& Gosh, 2010). Since no histopathological tests performed to support our findings, we stipulated that tannins at their high concentration levels and other active compounds (flavonoids, saponin, calcium oxalate and glycosides) contained in the T. catappa leaves (Tercas et al., 2017) have the potential to decrease the $\mathrm{pH}$ and ultimately caused mortality in the tested cyprinid species.
Total ammonia-nitrogen (TAN) is also another significant contributor to fish mortality other than tannins. Ammonia ionizes and deionizes the aquaculture system into $\mathrm{NH}_{4}+$ and $\mathrm{NH}_{3}$, respectively, which can be toxic depending on the levels present and fish species tolerance (Roberts \& Palmeiro, 2008). Generally, any decomposing organic residue from the plant and fish waste has a great potential to raise the ammonia and $\mathrm{pH}$ levels in the water as protein break downs (Ip \& Chew, 2010; Yavuzcan et al., 2017). Malaysia has set specific standards for acceptable and safety levels of TAN (ionized and unionized) for freshwater and marine fishes at $0.3 \mathrm{mg} / \mathrm{L}$ (DOF, 2016; White et al., 2008). At a low concentration of deionized ammonia of 0.05 $\mathrm{mg} / \mathrm{L}$, harmful effects such as poor growth rate, reduced fertility, increased stress, and susceptibility to disease could result in fish (da Silva et al., 2013). Meanwhile, at a high concentration that exceeds $2.0 \mathrm{mg} / \mathrm{L}$, gills, and tissues can be damaged and ultimately causes mortality and death to the fish (Ip $\&$ Chew, 2010). TAN concentration in the present study found slightly higher in the control but extremely elevated $(>3.5 \mathrm{mg} / \mathrm{L})$ when the concentrations of leaves extract concurrently increased (Table 3). These evidences have enough to demonstrate that insignificant TAN concentration responsible to cause toxics to all tested cyprinid species in this study. However, other factors that influence the vulnerability of targeted fishes on TAN should consider as well. The toxicity level of TAN according to the standard is also dependent on the fish's 
biological traits, sensitivity and adaptation levels to the affected environmental system (Wang et al., 2016). Remarkably, saltwater fish species found to be more sensitive to ammonia toxicity effects as compared to freshwater fish species according to Roberts and Palmeiro (2008). Therefore, we found that the tolerable capacity of our tested fishes varied towards the changes in their living environment even if they are from the same family. Goldfish managed to show higher tolerance than carp and barb in acidic $\mathrm{pH}$ condition and TAN concentration caused by the leaves extract immersion of T. catappa. Hence, overall results from this study can contribute significant knowledge to the aquaculture and local communities on the safety margin of these leaves to be utilized for their cultured fishes and provide promising insight into other potential use of T. catappa leaves extracts in fish ornamental industry.

\section{CONCLUSION}

The present study showed different effects of cyprinid species in various bath immersions of $T$. catappa leaves extract. The most tolerable threshold or safety concentration boundaries of the T. catappa leaves extract for all tested cyprinids were obtained up to $200 \mathrm{mg} / \mathrm{L}$, where no mortality recorded among them. All tested cyprinids shared an almost similar $\mathrm{LC}_{50}$ between 300 and $350 \mathrm{mg} / \mathrm{L}$. Further study based on these findings may be necessary to investigate the effectiveness of these leaves extract in improving the cyprinids' health and growth in a long term treatment.

\section{ACKNOWLEDGEMENT}

This study was financially supported by the Ministry of High Education (Malaysia) under the Fundamental Research Grant Scheme (FRGS Grant Number: FRGS/2/2014/ STWN03/UNISEL/03/1). The authors would like to thank National Fish Health Research Division of Fisheries Research Institute, Malaysia for the consultation, assistance and constructive suggestions in this research.

\section{REFERENCES}

Akinsanya, B., Utoh, O. U., \& Ukwa, U. D. (2016). Toxicological, phytochemical and anthelminthic properties of rich plant extracts on Clarias gariepinus. The Journal of Basic and Applied Zoology, 74, 75-86. https://doi.org/10.1016/j. jobaz.2016.09.003

Allyn, O. Q., Kusumawati, E., \& Nugroho, R. A. (2018). Antimicrobial activity of Terminalia catappa brown leaf extracts against Staphylococcus aureus ATCC 25923 and Pseudomonas aeruginosa ATCC 27853. Retrieved May 18, 2020, from https://www.ncbi. nlm.nih.gov/pmc/articles/PMC6206604/

Azrul, L. M., Nurulaini, R., Adzemi, M. A., Marina, H., \& Effendy, A. W. M. (2014). Tannins quantification in Terminalia catappa leaves extract and antihelmenthic potential evaluation. Journal of Natural Products, 7, 98-103.

Borisutpeth, P., Hanjavani, C., Luangpirom, A., \& Lawhavinit, O. (2001). Acute effect of tannic acid on intestine, liver and kidney of Oreochromis niloticus (L.). Khon Kaen University (KKU) Science Journal, 31(3), 157-166.

Bryan, M. N. (2016). Terminalia catappa (Talisay) leaves for preliminary surface water treatment: An eco-friendly approach. Natural Products 
Chemistry and Research, 5(249), 2. doi: 10.4172/2329-6836.1000249

Chansue, N., \& Assawawongkasem, N. (2008). The in vitro antibacterial activity and ornamental fish toxicity of the water extract of Indian almond leaves (Terminalia catappa Linn.). Khon Kaen University (KKU) Veterinary Journal, 18(1), 36-45.

Chansue, N. (2007). Effects of dried Indian almond leaf (Terminalia catappa L.) extract on monogenean parasites in goldfish (Carassius auratus). Wiener Tierarztliche Monatsschrift, 94(11-12), 269-273.

Chitmanat, C., Tongdonmuan, K., Khanom, P., Pachontis, P., \& Nunsong, W. (2005). Antiparasitic, antibacterial, and antifungal activities derived from a Terminalia catappa solution against some tilapia (Oreochromis niloticus) pathogens. Acta Horticulture, 678, 179182. doi: org/10.17660/ActaHortic.2005.678.25

Citarasu, T. (2010). Herbal biomedicines: A new opportunity for aquaculture industry. Aquaculture International, 18(3), 403-414. do: 10.1007/ s10499-009-9253-7

Citarasu, T. (2012). Natural antimicrobial compounds for use in aquaculture. In B. Austin (Ed.), Infectious disease in aquaculture: prevention and control (pp. 419-446). Philadelphia, USA: Woodhead Publishing Limited.

da Silva, F. J. R., dos Santos Lima, F. R., do Vale, D. A., \& do Carmo, M. V. (2013). High levels of total ammonia nitrogen as $\mathrm{NH}_{4}^{+}$are stressful and harmful to the growth of Nile tilapia juveniles. Acta Scientiarum-Biological Sciences, 35(4), 475-481. doi: 10.4025/actascibiolsci. v35i4.17291

Department of Fisheries Malaysia. (2015). Value of ornamental fish by State in RM. Retrieved June 02, 2019, from http://www.dof.gov.my/index. php/pages/view/115
Department of Fisheries Malaysia. (2016). List of registered ornamental fish exporters. Retrieved July 04, 2019, from http://www.dof.gov.my/ dof $2 /$

Ekanem, A. P., Obiekezie, A., Kloas, W., \& Knopf, K. (2004). Effects of crude extracts of Mucuna pruriens (Fabaceae) and Carica papaya (Caricaceae) against the protozoan fish parasite Ichthyophthirius multifillis. Parasitology Research, 92(5), 361-366. doi: 10.1007/s00436003-1038-8.

Fakoya, S., Olusola, S. E., \& Arifalo, O. V. (2019). Sensitivity of fish pathogenic bacteria to almond (Terminalia catappa) leaves and bitter (Vernonia amygdalina) leaves extracts. International Journal of Oceanography and Aquaculture, 3(1), 1-8. doi: 10.23880/ijoac-16000158

Ikhwanuddin, M., Julia, H. Z. M., Manan, H., NoorHidayati, A. B., Aina-Liyana, N. M. A., \& Juneta, A. S. N. (2014). Effect of Indian almond, Terminalia catappa leaves water extract on the survival rate and growth performance of black tiger shrimp, Penaeus monodon post larvae. AACL Bioflux, 7(2), 85-93.

Ip, Y. K., \& Chew, S. F. (2010). Ammonia production, excretion, toxicity and defence in fish: A review. Frontiers in Physiology (Aquatic Physiology), 1(134), 1-20. doi: 10.3389/fphys.2010.00134

Kadam, P. V., Yadav, K. N., Narappanawar, N. S., Shivatare, R. S., Bhusnar, H. U., \& Patil, M. J. (2011). Development of quality standards of Terminalia catappa leaves. Pharmacognosy Journal, 3(26), 19-24. doi: 10.5530/pj.2011.26.4

Kasthuri, O. R., \& Ramesh, B. (2018). Toxicity studies on leaf extracts of Alternanthera brasiliana (L.) Kuntze and Alternanthera bettzickiana (Regel) Voss. Journal of Applied Pharmaceutical Science, 8(10), 82-89. doi: 10.7324/JAPS.2018.81011

Lee, S. W., Farhan, R., Wee, W., Wan Zahari, M., \& Ibrahim C. O. (2016). The effects of tropical 
almond Terminalia catappa L., leaf extract on breeding activity of siamese gourami, Trichogaster pectoralis. International Journal of Fisheries and Aquatic Studies, 4(4), 431-433.

Liu, Y. M., Zhang, Q. Z., Xu, D. H., Fu, Y. W., Lin, D. J., Zhou, S. Y., \& Li, J. P. (2017). Antiparasitic efficacy of curcumin from Curcuma longa against Ichthyophthirius multifiliis in grass carp. Veterinary Parasitology, 236, 128-136. doi: 10.1016/j.vetpar.2017.02.011

Manaharan, T., Chakravarthi, S., Radhakrishnan, A. K., \& Palanisamy, U. D. (2014). In vivo toxicity evaluation of a standardized extract of Syzygium aqueum leaf. Toxicology Reports, 1, 718-725. doi: 10.1016/j.toxrep.2014.09.006

Mandal, S., \& Gosh, K. (2010). Accumulation of tannin in different tissues of Indian major carps and exotic carps. Aquaculture Research, 41(6), 945-948. doi: 10.1111/j.1365-2109.2009.02371.x

Marimuthu, P. N., Periyannan, R., Girijakumari, N. R., \& Ramar, M. (2012). Isolation, characterization of Vibrio and Pseudomonas spp. from infected fresh water ornamental fishes and evaluation of potential agents for its control. Research in Biotechnology, 3(6), 14-23.

Nugroho, R. A., Manurung, H., Nur, F. M., \& Prahastika, W. (2017). Terminalia catappa L. extract improves survival, haematological profile and resistance to Aeromonas hydrophila in Betta sp. Archives of Polish Fisheries, 25(2), 103-115. doi: 10.1515/aopf-2017-0010

Purivirojkul, W. (2012). Potential application of extracts from Indian almond (Terminalia catappa Linn.) leaves in Siamese fighting fish (Betta splendens Regan) culture. Communications in Agricultural and Applied Biological Sciences, 77(4), 439-448.

Purwani, K. I., Alami, N. H., Nurhatika, S., Marcilia, S. N., \& Arifiyanto, A. (2015). In vitro potential test of ketapang (Terminalia catappa) leave extract against Aeromonas salmonicida. Journal of Applied Environmental and Biological Sciences, 5(7), 1-6.

Roberts, H., \& Palmeiro, B. S. (2008). Toxicology of aquarium fish. Veterinary Clinics: Exotic Animal Practice, 11(2), 359-374. doi: org/10.1016/j. cvex.2007.12.005

Rodger, H. D. (2016). Fish disease causing economic impact in global aquaculture. In A. Adams (Ed.), Fish vaccines (pp. 1-34). Stirling, Scotland, Springer.

Saad, B., Azaizeh, H., Abu-Hijleh, G., \& Said, S. (2006). Safety of traditional Arab herbal medicine. Evidence-Based Complementary Alternative Medicine, 3(4), 433-439. doi: 10.1093/ecam/nel058

Singh, D., \& Singh, A. (2002). Piscicidal effect of some common plants of India commonly used in freshwater bodies against target animals. Chemosphere, 49(1), 45-49. doi: 10.1016/S00456535(02)00178-9

Song, K., Ling, F., Huang, A., Dong, W., Liu, G., Jiang, C., ... Wang, G. (2015). In vitro and in vivo assessment of the effect of antiprotozoal compounds isolated from Psoralea corylifolia against Ichthyophthirius multifiliis in fish. International Journal for Parasitology: Drugs and Drug Resistance, 5(2), 58-64. doi: 10.1016/j. ijpddr.2015.04.001

Stone, N., Shelton, J. L., Haggard, B. E., \& Thomforde, H. K. (2013). Interpretation of water analysis reports for fish culture. Stoneville, USA: Southern Regional Aquaculture Center Publication.

Stratev, D., Zhelyazkov, G., Noundou, X. S., \& Krause, R. W. M. (2018). Beneficial effects of medicinal plants in fish diseases. Aquaculture International, 26(1), 289-308. doi: 10.1007/ s10499-017-0219-x

Tercas, A. G., De-Souza Montero, A., Moffa, E. B., Dos-Santos, J. R. A., De-Sousa, E. M., Pinto, A. R. B., ... De-Andrade Monteiro, C. 
(2017). Phytochemical characterization of Terminalia catappa Linn. extracts and their antifungal activities against Candida spp. Frontiers in Microbiology, 8, 595. doi: 10.3389/ fmicb.2017.00595

Walczak, N., Puk, K., \& Guz, L. (2017). Bacterial flora associated with diseased freshwater ornamental fish. Journal of Veterinary Research, 61(4), 445449. doi: 10.1515/jvetres-2017-0070

Wang, W., Wang, H., Yu, C., \& Jiang, Z. (2016). Acute toxicity of ammonia and nitrite to different ages of Pacific cod (Gadus macrocephalus) larvae. Chemical Speciation and Bioavailability, 27(4), 147-155. doi: 10.1080/09542299.2015.1113389

White, P. G., Cromey, C. J., Palerud, R., Hernandez, J., Rosario, W., Regpala R. \& Lopez, N. (2008). PHILMINAQ Project 2 - Mitigating impact from aquaculture impact in the Philippines (6th Framework Programme: 8/2006 to 2/2008): Water quality criteria and standards for freshwater and marine aquaculture. Retrieved March 12, 2017, from http://www.aquaculture. asia

Yavuzcan Y, H., Robaina, L., Pirhonen, J., Mente, E., Dominguez, D., \& Parisi, G. (2017). Fish welfare in aquaponic systems: Its relation to water quality with an emphasis on feed and faeces-A review. Water, 9(13), 1-17. doi: 10.3390/w9010013

Yi, L. Y., Lu, C., Hu, G. X., Ling, F., \& Wang, G. X. (2012). Antiprotozoal activity of medicinal plants against Ichthyophthirius multifiliis in goldfish (Carassius auratus). Parasitology Research, 11(1), 147-155.

Yunus, K., Jaafar, A. M., \& John, A. (2019). Acutelethal toxicity $\left(\mathrm{LC}_{50}\right)$ effect of Terminalia catappa Linn. leaves extract on Oreochromis niloticus (red Nile tilapia) juveniles under static toxicity exposure. Oriental Journal of Chemistry, 35(1), 270-274. 